\author{
(online) $=$ ISSN $2285-3642$ \\ ISSN-L = $2285-3642$ \\ Journal of Economic Development, Environment and People \\ Volume 2, Issue 3, 2013 \\ URL: $\underline{\text { http://jedep.spiruharet.ro }}$ \\ e-mail: office jedep@spiruharet.ro
}

\title{
The Impact of Globalization on Economies of Developed Countries
}

\author{
Mgr. Lenka Pelegrinová, PhD. ${ }^{1}$, Ing. Martin Lačný, PhD. ${ }^{1 \text { [1] }}$ \\ ${ }^{1}$ University of Prešov, Slovakia
}

\begin{abstract}
.
The concept of globalization is interpreted by various authors in terms of its importance or content. Thisarticlepresents results of an analysis of the influence of globalization trends on important macroeconomic indicators of selected countries. An examination of the level of globalization as a quantitative marker was enabled by the KOF Index of Globalization, which provides an indication of the economic, political and social globalization at global level. Research methods included time series analysis, trend analysis and nonparametric regression model (regression of panel data).
\end{abstract}

Keywords: Economic Globalization, Political Globalization, Social Globalization, KOF Index of Globalization, Open Economy

JEL Codes: F01, F21, F43, F62, F63

\section{Introduction}

An often inflected term globalization is associated principally with spontaneous and uncontrolled process that affects events at a global level, while also transforming a daily life of individuals. In a globalizing world, in a time full of paradoxes and unprecedented dynamics we are drawn into events that cannot be avoided. The character of society is changing and it is not reducible to a certain territory, nation or culture anymore. Therefore, globalization is usually understood as a process of integration at a higher quality level, compared with previous historical stages of the society development. It identifies the fact that there is a level of the global interdependence, integration and organization that covers existing national, regional and local systems.

Globalization refers to the process of the gradual disappearance of borders of nation-states, while economic globalization represents the pinnacle of this process. The evidence can be found in the interdependence of economies around the world, where each economy is sensitive to fluctuations and changes in other economies. This sensitivity is naturally determined by the intensity of market coupling. However, also a low intensity of market coupling may have indirect effects through the global economy

\footnotetext{
${ }^{+}$Corresponding author - Tel.: + 421 (0)51 7724380 E-mail address: martin.lacny@unipo.sk
} 


\author{
(online) $=$ ISSN $2285-3642$ \\ ISSN-L = 2285-3642 \\ Journal of Economic Development, Environment and People \\ Volume 2, Issue 3, 2013 \\ URL: $\underline{\text { http://jedep.spiruharet.ro }}$ \\ e-mail: office jedep@spiruharet.ro
}

network. Economic globalization is thus a process in which national markets and economies gradually open up to competition, capital, technology and information. It means also introduction of general rules and laws regulating national economies. From the perspective of political globalization, one can perceive in particular the impact of international organizations on the national legislations. Social and cultural globalization is being considered also as a significant aspect, which is intensified by the growing trend of using the internet and social networks within the last decade.

The debate about globalization is facing various opinion streams that perceive the process of globalization in positive or negative terms. Despite the different opinions all parties agree that globalization is an intensifying and inevitable phenomenon. According to Shangquana (2000) globalization presents increasing interdependence of world economies as a result of the growth of cross-border flows of goods, services, international capital and quickly spreading technologies. Acceleration of the economic globalization in recent years is related to the rapid development of science and technology, which caused a continuous cost reduction in transport, communication, international trade and investment, thus enabling the organization and coordination of global production.

Heterogeneity of the perception of globalization is presented e.g. by Baylis and Smith (2008), who divided various debates on globalization into four groups of international politics theories: realism, liberalism, Marxist theory and social constructivism. The diversity of views on globalization is highlighted also by Heldand McGrew(1999), who distinguish three main theoretical streams: hyper-globalism, skepticism and transformationalism. Among the frequentlycited authorswe reflect also Scholte(2000), who offers a different perception of globalization as he distinguishes authors, who see globalization in terms of its origin, influence and impact on society.

The consequences of globalization are perceived especially in terms of the traditional conflict between developed and developing countries. For the least developed countries it becomes difficult to identify the causes of their failure and inability to take advantage of globalization processes as well as the developed ones. Therefore, we aimed our research on smaller and larger national economies, focusing on the impact of the globalization on the development of selected macroeconomic indicators during the 15-year period. The aim of the research is to verify the impact of globalization on economic development in selected countries through panel data regression.

\title{
2. KOF Index of Globalization
}

A quantification of the level of globalization was enabled at the global scale by the KOF Index of Globalization, which was first introduced in 2002 and updated in 2012 to its current form. Data of the KOF Index of Globalization are now available on a yearly basis for 208 countries over the period of 1970-2009. Authors of the KOF Index of Globalization perceive globalization as a process of networking and building relations between actors across continents through various streams: people, information, ideas, capital, products and services. Globalization is thus the process of erosion of national boundaries that integrates 


\author{
(online) $=$ ISSN $2285-3642$ \\ ISSN-L = 2285 - 3642 \\ Journal of Economic Development, Environment and People \\ Volume 2, Issue 3, 2013 \\ URL: http://jedep.spiruharet.ro \\ e-mail: office jedep@spiruharet.ro
}

national economies, cultures, technologies and governments, forming a complex system of interdependent relations. (KOF Index of Globalization, 2012)KOF Index of Globalization is the only leading index, which provides indications of the level of globalization in different countries in three main areas:

- Economic globalization;

- Social globalization;

- Political globalization.

Economic globalization is characterized by flows of products, services, capital and information flows relating to market activity over a longer distance. On the other hand, social globalization concerns mainly a dissemination of ideas, information, and people in particular. Globalization at the political level characterizes the dispersion and linking of government policies.

The calculation of three sub-indices in these three areas (economic, social and political) forms the basis for the calculation of the overall index of globalization level, which covers:

- Actual economic flows;

- Economic constraints;

- Data on information flows;

- Data on personal contacts;

- Data on cultural proximity.

A graphical representation of the KOF Index of Globalization is presented on the Figure 1 and exact values of the index for each country during the period of 1995-2009 are shown in the Table 1.

\begin{tabular}{|c|c|c|c|c|c|c|c|c|}
\hline \multicolumn{9}{|c|}{ KOF Index of Clobalization } \\
\hline \multicolumn{2}{|c|}{ Economic globalization } & \multirow{2}{*}{$36 \%$} & \multicolumn{2}{|c|}{ Social globalization } & \multirow{2}{*}{$\begin{array}{l}37 \% \\
\text { Value }\end{array}$} & \multicolumn{2}{|l|}{ Political globalization } & \multirow{2}{*}{$\frac{26 \%}{\text { Value }}$} \\
\hline Sub-index & Cathegory & & Sub-index & Cathegory & & Sub-index & Cathegory & \\
\hline \multirow[t]{5}{*}{ Actual flows } & & $50 \%$ & Personal contac & & $34 \%$ & Political engagement & & $26 \%$ \\
\hline & Trade & $21 \%$ & & Telephone traffic & $25 \%$ & & Embassies in country & $25 \%$ \\
\hline & Foreign direct investment & $28 \%$ & & Transfers & $4 \%$ & & Membership in international organizations & $28 \%$ \\
\hline & Portfolio investment & $24 \%$ & & International tourism & $26 \%$ & & Participation in U.N. Security Council missions & $22 \%$ \\
\hline & Income payments to foreign nationals & $27 \%$ & & Foreign population & $21 \%$ & & International treaties & $25 \%$ \\
\hline \multirow[t]{9}{*}{ Restrictions } & & $50 \%$ & & International letters & $25 \%$ & & & \\
\hline & Hidden import barriers & $24 \%$ & Information flou & & $35 \%$ & & & \\
\hline & Mean tarifi rate & $27 \%$ & & Internet users & $33 \%$ & & & \\
\hline & Taxes on international trade & $26 \%$ & & Television & $36 \%$ & & & \\
\hline & Capital account restrictions & $23 \%$ & & Trade in newspapers & $32 \%$ & & & \\
\hline & & & Cultural proxim & & $31 \%$ & & & \\
\hline & & & & Number of McDonald's restaurants & $44 \%$ & & & \\
\hline & & & & Number of kea & $45 \%$ & & & \\
\hline & & & & Trade in books & $11 \%$ & & & \\
\hline
\end{tabular}

Fig. 1: Structure of KOF Index of Globalization

(Own processing according to KOF Index of Globalization, 2012) 


\author{
(online) $=$ ISSN $2285-3642$ \\ ISSN-L = 2285 - 3642 \\ Journal of Economic Development, Environment and People \\ Volume 2, Issue 3, 2013 \\ URL: http://jedep.spiruharet.ro \\ e-mail: office jedep@spiruharet.ro
}

Table 1: Values of the KOF Index of Globalization in selected countries during the period 1995-2009

(Own processing according to KOF Index of Globalization, 2012)

\begin{tabular}{|c|c|c|c|c|c|c|c|c|c|c|c|c|c|c|c|c|}
\hline Code & Country & 1995 & 1996 & 1997 & 1998 & 1999 & 2000 & 2001 & 2002 & 2003 & 2004 & 2005 & 2006 & 2007 & 2008 & 2009 \\
\hline CZE & Czech Republic & 72.95 & 73.70 & 75.40 & 76.69 & 78.55 & 80.03 & 81.38 & 82.39 & 82.32 & 84.62 & 85.40 & 85.34 & 86.48 & 86.00 & 85.76 \\
\hline FIN & Finland & 76.89 & 82.68 & 83.65 & 85.10 & 85.96 & 87.24 & 87.13 & 86.25 & 85.90 & 86.76 & 85.17 & 85.67 & 86.62 & 85.70 & 84.34 \\
\hline FRA & France & 78.56 & 78.51 & 79.72 & 81.05 & 81.41 & 83.39 & 82.27 & 82.55 & 82.73 & 83.85 & 83.45 & 84.03 & 84.68 & 84.34 & 84.11 \\
\hline DEU & Germany & 74.29 & 75.55 & 77.10 & 78.71 & 79.95 & 81.70 & 81.47 & 82.13 & 82.17 & 81.99 & 82.22 & 82.47 & 83.02 & 82.09 & 81.52 \\
\hline HUN & Hungary & 74.93 & 76.49 & 78.24 & 79.86 & 80.49 & 80.87 & 81.95 & 80.92 & 80.91 & 84.62 & 85.29 & 86.57 & 86.90 & 86.90 & 87.37 \\
\hline IRL & Ireland & 82.46 & 83.73 & 84.13 & 85.58 & 85.85 & 86.75 & 87.23 & 86.30 & 86.26 & 86.00 & 86.88 & 86.19 & 86.48 & 86.01 & 91.95 \\
\hline NLD & Netherlands & 88.36 & 88.54 & 89.02 & 89.87 & 91.13 & 91.81 & 91.38 & 90.44 & 91.29 & 90.52 & 90.52 & 91.00 & 91.93 & 91.50 & 90.94 \\
\hline NOR & Norway & 81.10 & 82.09 & 82.57 & 83.22 & 82.65 & 83.15 & 82.96 & 81.75 & 83.31 & 81.70 & 80.36 & 81.76 & 82.56 & 82.29 & 83.19 \\
\hline RUS & Russian Federation & 51.68 & 52.52 & 53.84 & 56.37 & 57.80 & 63.80 & 64.95 & 66.29 & 66.93 & 66.84 & 67.05 & 66.99 & 68.01 & 65.65 & 67.34 \\
\hline SVK & Slovak Republic & 63.36 & 65.31 & 67.29 & 68.75 & 70.26 & 72.88 & 74.01 & 72.80 & 72.98 & 80.62 & 82.35 & 83.41 & 83.85 & 84.05 & 83.83 \\
\hline GBR & United Kingdom & 83.97 & 84.33 & 85.07 & 85.64 & 86.43 & 87.04 & 86.58 & 86.53 & 86.90 & 85.96 & 86.45 & 86.16 & 85.99 & 85.62 & 85.53 \\
\hline USA & United States & 74.94 & 75.39 & 75.75 & 75.93 & 76.37 & 76.86 & 76.11 & 75.09 & 75.54 & 76.24 & 76.29 & 77.07 & 77.53 & 76.40 & 74.87 \\
\hline
\end{tabular}

\title{
3. Aims and Methods of Research
}

Globalizationpresents a controversial issue inprofessional, scientific, orpolitical discourse. It is mainly seenin terms of positive, respectivelynegative impacton thesocietyin particular countries. Forourresearchwe selectedso called developed countriesin the EuropeanandNorth Americancontinentwith comparableeconomicandpolitical systems. We worked at our researchwith the basic assumptionthat the level ofglobalizationisreflectedpositivelyin the context of economicdevelopment of selectedcountries.

\section{Aim of the research}

The aim of research was to verify the relationship between the level of globalization and economic indicators in selected countries of the research sample. The performance criterion of the main aim is to verify scientific hypothesis $(\mathrm{H})$ :

The higher the level of globalization in selected countries, the more positively manifested selected macroeconomic indicators in countries in the research sample.

\section{Research sample}

For the purpose of research, we selected twelve countries of the European and the North American continent that could be divided into three basic groups:

1. World powers with significant economic and political engagement at a global level: United States of America (USA), Russian Federation (RUS), Germany (DEU), United Kingdom of Great Britain and Northern Ireland (GBR), French Republic (FRA).

2. Economically and politically developed European countries with influence mainly at a regional level: Finland (FIN), Netherlands (NLD), Ireland (IRL), Norway (NOR). 


\author{
(online) $=$ ISSN $2285-3642$ \\ ISSN-L = 2285 - 3642 \\ Journal of Economic Development, Environment and People \\ Volume 2, Issue 3, 2013 \\ URL: $\underline{\text { http://jedep.spiruharet.ro }}$ \\ e-mail: office jedep@spiruharet.ro
}

3. Smaller post-socialist economies of Central Europe: Czech Republic (CZE), Slovak Republic (SVK), Hungary (HUN).

In the terms of representativeness, the research sample represents $6.2 \%$ of the overall number of countries, if we take into account the number of UN members (193 countries). However, in terms of the global economy, selected countries represent a significant share of global production, according to the IMF about $80 \%$ of the world production.

\title{
Research methods
}

For the research, in addition to basic theoretical and logical methods (analysis, synthesis, deduction, induction, comparison, analogy, abstraction, and concretization), there were used also basic methods of descriptive statistics (linear graphs, tables), time series analysis through trend analysis and nonparametric regression model (regression of panel data).

As a matter of the panel data regression we worked with the analysis of time series (1995-2009) and with a sample of 12 countries, representing a set of 180 observations. Panel data are combined time and spatial data that are expressed as time series of observations for each country in the period 1995-2009. For the basic regression model of panel data we consider following model (Lukáčik, Lukáčiková, Szomolányi, 2010):

$$
y_{i t}=\beta_{1} x_{i t 1}+\beta_{2} x_{i t 2}+\ldots+\beta_{k} x_{i t k}+\alpha_{1} z_{i 1}+\alpha_{2} z_{i 2}+\ldots+\alpha_{q} z_{i q}+u_{i t}
$$

The index $i$ denotes the cross-sectional dimension $i=1, \ldots, n$, that are 12 countries of the research sample and the index $t$ denotes the time dimension $t=1, \ldots, T$, that is the time period from 1995 to 2009. Variables $x_{1}$ to $x_{k}$ are explanatory variables that do not include units vector and variables $z_{1}$ to $z_{q}$ representing individual effects - diversity, which may differ a country or a whole group from other entities are classified here as the units vector. Individual effects do not change with time. $U_{i t}$ are independent and equally distributed errors with zero mean and dispersion $\sigma_{2}$ (homoskedasticity assumption).

Panel regression allows us to determine the relationship between KOF Index of Globalization (KOF) as the explaining variable and explanatory variables that represent foreign direct investments (FDI), balance of payments (B) and GDP per capita. All economic indicators are expressed in U.S. dollars according to the current exchange rate.

Foreign direct investment represents a category of international investment expressed as an absolute value of the current USD. It expresses the intention of an entity residing in one economy (direct investor) to obtain a lasting interest in an enterprise residing in another economy (direct investment enterprise) (International Monetary Fund, 1993, p.93). 


\author{
(online) $=$ ISSN $2285-3642$ \\ ISSN-L = $2285-3642$ \\ Journal of Economic Development, Environment and People \\ Volume 2, Issue 3, 2013 \\ URL: $\underline{\text { http://jedep.spiruharet.ro }}$ \\ e-mail: office jedep@spiruharet.ro
}

Balance of payments is defined as a statistical summary of capturing economic transactions between residents of one country and residents of the rest of the world during the reference period. The balance of payments is compiled on a monthly basis in cumulative form in the current absolute value of USD (International Monetary Fund, 1993, p. 10-19).

GDP per capita is gross domestic product (GDP) divided by the average annual number of inhabitants of the country, allowing efficient comparison of the performance of economies of selected countries, irrespective of their size or population.

As mentioned above, we worked with an assumption that globalization has a positive impact on all selected economic indicators. By opening up to globalization the country should become more attractive for foreign investors (FDI growth), the volume of exports to other countries should increase (growth of B) and the overall economic situation of the country should improve (growth of GDP per capita).

\title{
4. Results of the Research
}

The research was aimed to identify the relationship between globalization and selected economic indicators, while we would like to answer questions about the impact of globalization on the economic development of countries. First, it was necessary to determine the mode that should properly quantify the level of globalization. As the most appropriate we consider the KOF Index of Globalization, which takes into account not only economic, but also political and social sphere of globalization. Data on the development of the KOF Index of Globalization in selected countries of the research sample for the period 1995 - 2009 are shown in Table 1.The values of the explanatory variables (FDI, B, GDP per capita) were obtained from publicly available databases (World Trade Organization, World Bank, International Monetary Fund). They were subsequently used in the panel regression (regression of panel data), which allows to determine the linear relationship between explaining and explanatory variables.

For the purposes of scientific research, we reformulate the scientific hypothesis $\mathrm{H}$ to three alternative statistical hypotheses $\mathrm{H} 1$ - H3:

H1: There is a statistically significant relationship between the KOF Index of Globalization (KOF) and foreign direct investments (FDI).

H2: There is a statistically significant relationship between the KOF Index of Globalization (KOF) and balance of payments (B).

H3: There is a statistically significant relationship between the KOF Index of Globalization (KOF) and GDP per capita.

The verification of statistical hypotheses $\mathrm{H} 1-\mathrm{H} 3$ took place at the chosen significance level $\alpha(0,05)$. For the adoption of statistical hypotheses we consider as a guideline if the $p$-value (Probability Level) is less than the significance level $\alpha$. 


\author{
(online) $=$ ISSN $2285-3642$ \\ ISSN-L = 2285 - 3642 \\ Journal of Economic Development, Environment and People \\ Volume 2, Issue 3, 2013 \\ URL: http://jedep.spiruharet.ro \\ e-mail: office jedep@spiruharet.ro
}

Statistical hypotheses were tested in EViews program using the Fixed Effect Model (FEM), which provides diversity of cross members in absolute units. Statistical hypothesis test results are shown in Table 2.

Table 2: Results of the statistical test of $\mathrm{H} 1, \mathrm{H} 2, \mathrm{H} 3$ (Own processing)

\begin{tabular}{||l|l|l||}
\hline $\begin{array}{l}\text { Dependent Variable: KOF } \\
\text { Method: Panel Least Squares } \\
\text { Total panel (balanced) observations: } 180\end{array}$ \\
\hline \multicolumn{3}{|l||}{} \\
\hline Variable & & \\
\hline FDI & t-Statistic & $p$-value \\
\hline Balance & 2.206328 & $\mathbf{0 . 0 2 8 7}$ \\
\hline HDP per capita & 0.728138 & 0.4675 \\
\hline
\end{tabular}

The result of the testing of statistical hypotheses points to a statistically significant linear relationship between the KOF Index of Globalization and foreign direct investment. Similarly, the test confirmed a significant linear relationship between the KOF Index of Globalization and GDP per capita, where the testing result shows almost zero probability of a random effect. In both cases it is a positive dependence, so at the growth of KOF there is an evident increase of FDI and GDP per capita in selected countries. The testing of the hypothesis $\mathrm{H} 2$, however, did not point to the relationship between the growth of KOF and the balance of payments of countries.

Based on the results of testing, we are able to confirm the scientific hypothesis $\mathrm{H}$. Despite the statistical analysis has not confirmed relationship between an increase of the KOF Index of Globalization and the balance of payments, we assume that this indicator has no direct positive or negative impact on the national economies. By contrast, GDP per capita shows the performance of national economies independent on their size (land area, population). Foreign direct investments (FDI) also have a direct impact on the national economies, and their increased occurrence is considered a positive economic phenomenon.

Opening up to globalization represents an effort to minimize the economic, political, or cultural barriers. The result of the opening up should be a closer cooperation with other actors beyond national borders. Therefore we have chosen indicators which could confirm our assumption. Openness to globalization trends should attract foreign investment actors and it should be reflected in increasing foreign direct investments (FDI) into the country. Panel regressions confirmed this assumption and therefore we can conclude that increasing the level of globalization has a positive effect on increasing foreign direct investment.

Countries' participation on the process of economic globalization should increase their productivity and enable them to expand into foreign markets. The expansion is reflected in particular in improving their balance of payments. The testing of this hypothesis doesnot confirm our assumption. As a final indicator we 


\author{
(online) $=$ ISSN $2285-3642$ \\ ISSN-L = 2285 - 3642 \\ Journal of Economic Development, Environment and People \\ Volume 2, Issue 3, 2013 \\ URL: http://jedep.spiruharet.ro \\ e-mail: office jedep@spiruharet.ro
}

have chosen GDP per capita, which captures the most realisticallythe economic situation in the country. Openness to globalization promotes, as stated by many authors, an economic growth of developed economies, and thus the ratio of GDP per capita should grow. At the sample of countries we have successfully tested this statistical hypothesis and confirmed this conclusion, since the ratio of GDP per capita increased with the increasing of the KOF Index of Globalization, which points to the openness of countries to globalization.

\title{
5. Discussion - Globalization and Slovak Republic
}

Based on the research we confirmed the positive effect of globalization on foreign direct investment and GDP per capita. Thus, we can formulate a recommendation that the opening up to globalization has positive effects on national economies. From that perspective, we focused on the openness of the Slovak Republic to globalization, while considering the KOF Index of Globalization, as well as its sub-indices.

At detailed look on the results of Slovakia we can monitor the level of development of globalization during the period 1995-2009 on the following charts. Figure 2 shows the evolution of KOF indicator, the globalization index and its sub-indices, that reflect globalization in economic, political and social spheres. We notice that all indicators were rising continuously, while a significant breakthrough occurred in 2004, which is probably due to the entry into the European Union. We register the most significant jump in the sphere of economic globalization. Since 2004, no major breakthrough occurred in the development of globalization in Slovakia.

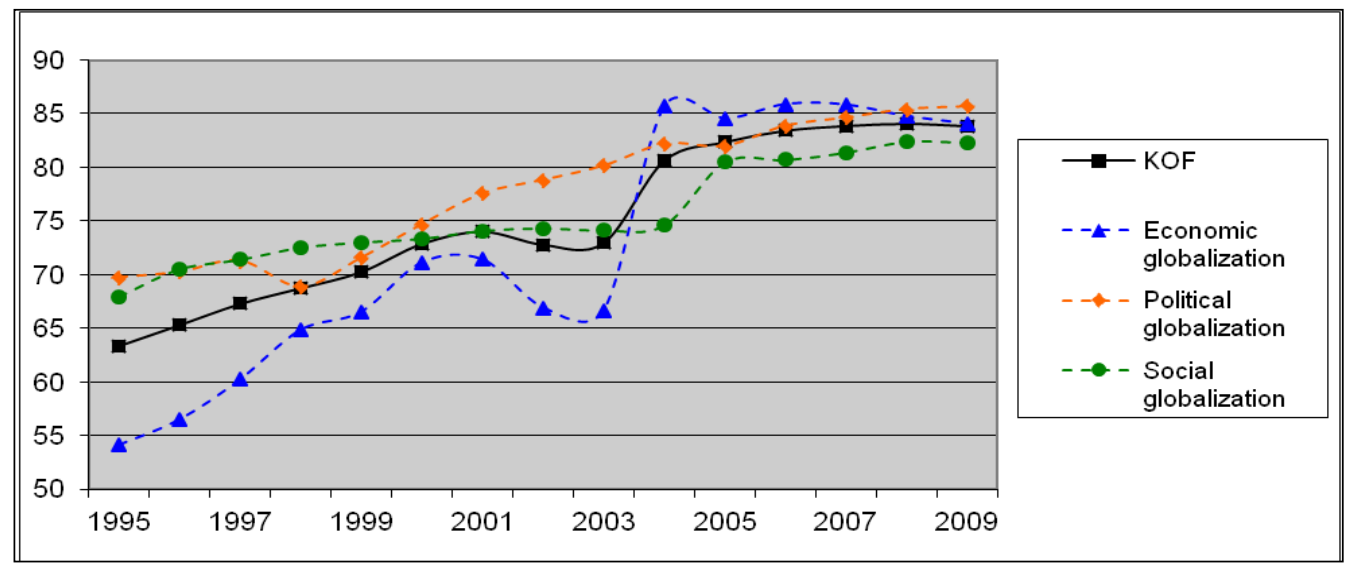

Fig. 2: Development of KOF Index of Globalization in Slovakia (1995 - 2009)

(Own processing)

On the basis of the globalization index for the period 1995 - 2009 we were able to simulate the development of indicators through trend analysis for the next five years. Thus, Figure 3 shows the expected development indicators in the period 2010-2015 in Slovakia. The development of indicators during the 15year period after the application of trend analysis points to continuous gradual growth of the globalization 


\author{
(online) $=$ ISSN $2285-3642$ \\ ISSN-L = $2285-3642$ \\ Journal of Economic Development, Environment and People \\ Volume 2, Issue 3, 2013 \\ URL: http://jedep.spiruharet.ro \\ e-mail: office jedep@spiruharet.ro
}

index and its sub-indices in the next 5-year period. Economic globalization is expressed most significantly and social globalization lags behind. Political globalization follows the predicted trend of the overall KOF Index of Globalization. As the trend analysis highlights the continued opening of Slovak republic to globalization in all fields, we can assume the main effect of this trend on the domestic economy.

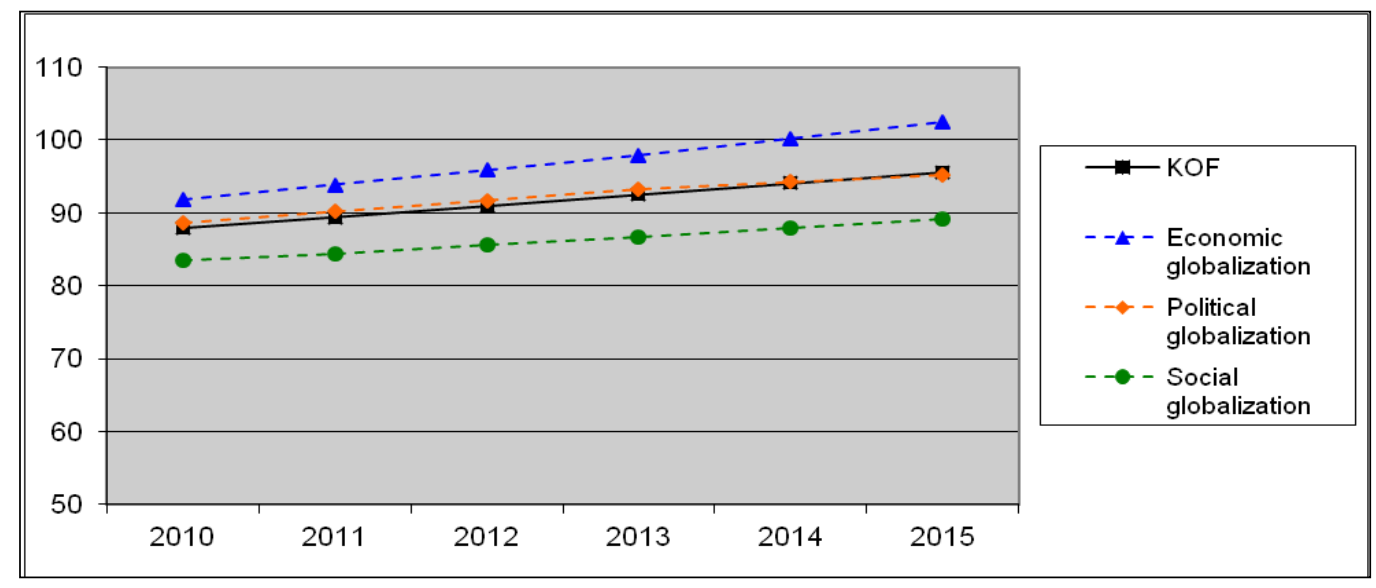

Fig. 3: Trend analysis of KOF Index of Globalization in Slovakia for the period 2010 - 2015

(Own processing)

\title{
6. Conclusion
}

The main aim of the research was to verify the relationship between the level of globalization and the development of selected macroeconomic indicators. An examination of the level of globalization as a quantitative marker was enabled by the KOF Index of Globalization, which provides an indication of the economic, political and social globalization at global level. KOF Index of Globalization has enabled us to follow the evolution of globalization in selected countries for the period of 1995 - 2009.

While studying the impact of globalization, we have chosen as explanatory variables the amount of foreign direct investments, which show the attractiveness of countries for foreign investors. At the same time, we focused on the balance of payments, which demonstrates the ability of the economy to succeed in foreign markets, as well as GDP per capita, which compares the gross domestic product of countries, regardless of their size. We assumed that globalization will have a positive impact on the development of these indicators.

Based on statistical hypothesis testing through regression panel data in EViews program, we were able to adopt statistical hypotheses, which predicted a statistically significant relationship between the KOF Index of Globalization and foreign direct investments (FDI) as well as GDP per capita. We could not, however, accept the hypothesis of a statistically significant relationship between the KOF Index of 


\author{
(online) = ISSN $2285-3642$ \\ ISSN-L = $2285-3642$ \\ Journal of Economic Development, Environment and People \\ Volume 2, Issue 3, 2013 \\ URL: http://jedep.spiruharet.ro \\ e-mail: office jedep@spiruharet.ro
}

Globalization and the balance of payments of selected countries. Overall, we have adopted the assumption of a positive impact of globalization on the economies of selected countries.

In the end, we have focused on the development of the level of globalization in Slovakia. Values of the KOF Index of Globalization and its sub-indices gradually increased, with the greatest breakthrough occurred after the accession to the European Union. Trend analysis highlighted the continuing upward trend of opening up to globalization in all areas.

\title{
7. References
}

[1] J. Baylis, J.,S. Smith, S. et al.The Globalisation of World Politics. New York: Oxford University Press, 2008,623 p. ISBN 978-0199297771.

[2] E. Cihelková, J. Křižková, H. Kunešová andD. Martinčík.Světová ekonomika- nové jevy a perspektivy.Praha: C.H. Beck, 2001, 257 p. ISBN 80-7179-311-6.

[3] A. Giddens. The Consequences of Modernity. Cambridge: Polity Press, 1990, 188 p. ISBN0-7456-0923-6.

[4] R. Gilpin. The Political Economy of International Relations. Princeton: Princeton University Press, 1987,472 p. ISBN: 9780691022628.

[5] D. Held, A. McGrew, et al. Global Transformations: Politics, Economics and Culture. Stanford: Stanford University Press, 1999, 540 p. ISBN 0804736278.

[6] International Monetary Fund. [online, quoted to 10.1.2013] Available at $\langle$ http://www.imf.org $>$.

[7] KOF Index of Globalization. [online, quoted to 10.1.2013] Available at <http://globalization.kof.ethz.ch/>.

[8] O. Krpec, P. Pšeja, et al.: Mezinárodní politická ekonomie. Brno: IIPS MU, 2006, 164 p. ISBN-10: 80-210-4121-8.

M. Lukáčik, A. Lukáčikováand K. Szomolányi. Panelové dáta v progeme EViews. Bratislava: Fakulta hospodárskej informatiky, Ekonommická univerzita v Bratislave, 2010. [online, quoted to 31.3.2011] Available at <http://www.fhi.sk/files/katedry/kove/veda-vyskum/prace/2010/Lukacik-Lukacikova-Szomolanyi2010b.pdf>.

[9] P. McMichael. Globalisation: Trend or Project?In:R. Palan,et al. Global Political Economy.London: Routledge, 2000, 286 p. ISBN 0-415-20489-5.

[10] G. Shangquan. Economic Globalisation: Trends, Risks and Risk Prevention. In: Economic \& Social Affairs, CDP Backround Paper No.1, 2000. [online, quoted to 10.1.2013] Available at <http://www.un.org/en/development/desa/policy/cdp/cdp background papers/bp2000 1.pdf>

[11] J. A. Scholte. Globalization - a critical introduction. New York: Palgrave Macmillan, 2000, 520 p. ISBN $978-$ 0333977026.

[12] G. Smith and G. Naím. Altered states: Globalisation, Sovereignty and Governance. Ottawa: International Development Research Centre, 2000, 79 p. ISBN 0-88936-917-8.

[13] The World Bank. [online, quoted to 10.1.2013] Available at $\langle$ http://data.worldbank.org $>$.

[14] World Trade Organisation. [online, quoted to 10.1.2013] Available at $\leq$ https://www.wto.org/>. 